\title{
PERBANDINGAN RANDEMEN MINYAK ATSIRI SEREH (Cymbopogon citratus) YANG UMUR PANENNYA 6 BULAN DAN 9 BULAN DENGAN METODE DESTILASI AIR
}

\author{
Rani Prabandari \\ Sekolah Tinggi Harapan Bangsa Purwokerto
}

\begin{abstract}
Abstrak
Alam Indonesia sangat kaya tumbuh-tumbuhan mengandung minyak atsiri. Minyak atsiri dapat dihasilkan dari berbagai bagian tanaman seperti akar, batang, daun, bunga, atau buah. Jenis tanaman penghasil minyak atsiri ada 50-200 spesies. Di Indonesia terdapat sekitar 40 jenis tanaman penghasil minyak atsiri. Salah satu tanaman penghasil minyak atsiri adalah sereh (Taufiq, Tuhana, 2008 p: 2). Penelitian ini bertujuan mengetahui perbandingan randemen minyak atsiri pada Sereh (Cymbopogon citratus) yang umur panennya 6 bulan dan 9 bulan dengan metode destilasi air. Prosedur pemilihan sampel dan sampel penelitian, langsung dengan objek penelitian yaitu tanaman sereh umur panennya 6 bulan diambil dari 1 rumpun dan 9 bulan diambil dari 1 rumpun. Hasil penelitian ini menunjukkan bahwa tanaman sereh yang umur panennya 6 bulan lebih banyak menghasilkan minyak atsiri dibandingkan dengan tanaman sereh yang umur panennya 9 bulan. Hal ini dipengaruhi oleh beberapa faktor, diantaranya iklim, umur panen. Tanaman sereh umur 6 bulan merupakan umur optimal untuk dipanen, sehingga mendapatkan rendemen minyak atsiri yang lebih besar, disamping itu faktor kesuburan tanah serta intensitas cahaya matahari juga berpengaruh terhadap kandungan minyak atsiri sereh. Dari hasil penelitian yang telah dilakukan pada sampel uji, dapat disimpulkan bahwa hasil randemen minyak atsiri pada tanaman sereh (Cymbopogon citratus) yang umur panenya 6 bulan diperoleh hasil randemen rata-rata $0,46 \% \mathrm{v} / \mathrm{b}$ dan 9 bulan diperoleh randemen rata-rata $0,35 \% \mathrm{v} / \mathrm{b}$ dengan hasil uji-t didapatkan harga t-hitung $(2,984)>\mathrm{t}$-tabel $(2,776)$. Sehingga $\mathrm{H}_{0}$ ditolak dan $\mathrm{H}_{\mathrm{a}}$ diterima dan dapat disimpulkan bahwa terdapat perbedaan yang signifikan antara sereh yang umur panennya 6 bulan dan 9 bulan.
\end{abstract}

Kata kunci: sereh, minyak atsiri, umur panen, destilasi air.

\begin{abstract}
Indonesian nature is very rich in plants containing essential oils. Essential oils can be produced from various parts of plants such as roots, stems, leaves, flowers, or fruit. There are 50-200 species of essential oil producing plants. In Indonesia there are around 40 types of essential oils producing plants. One of the essential oils producing plants is lemongrass (Taufiq, Tuhana, 2008 p: 2). This study aims to determine the comparison of essential oils in Lemongrass (Cymbopogon citratus) which are harvested at 6 months and 9 months with a water distillation method. The procedure for selecting samples and research samples, directly with the object of research, is the citronella plant whose harvest age is 6 months taken from 1 clump and 9 months taken from 1 clump. The results of this study indicate that lemongrass plants with a harvest age of 6 months produce more essential oils compared to lemongrass plants with a harvest age of 9 months. This is influenced by several factors, including climate, harvest age. Lemongrass plants aged 6 months are the optimal age to be harvested, so that they get a higher yield of essential oils, besides that the factors of soil fertility and the intensity of sunlight also affect the content of essential oils of lemongrass.

From the results of the research that has been done on the test sample, it can be concluded that the results of the essential oil ration on citronella (Cymbopogon citratus), which has 6 months of harvest age, obtained an average yield of $0.46 \% \mathrm{v} / \mathrm{b}$ and 9 months. $0.35 \% \mathrm{v} / \mathrm{b}$ with the results of the $t$-test obtained by the price $t$-count (2.984)> t-table (2.776). So that $\mathrm{HO}$ is rejected and $\mathrm{Ha}$ is accepted and it can be concluded that there is a significant difference between lemongrass with 6 months and 9 months of harvest.
\end{abstract}

Keywords: lemongrass, essential oil, age of harvest, water distillation 


\section{PENDAHULUAN}

Indonesia ditengarai sebagai salah satu negara penghasil minyak atsiri yang cukup penting di dunia. Alam Indonesia sangat kaya tumbuh-tumbuhan mengandung minyak atsiri. Minyak atsiri dapat dihasilkan dari berbagai bagian tanaman seperti akar, batang, daun, bunga, atau buah. Jenis tanaman penghasil minyak atsiri ada 50-200 spesies. Di Indonesia terdapat sekitar 40 jenis tanaman penghasil minyak atsiri. Salah satu tanaman penghasil minyak atsiri adalah sereh (Taufiq, Tuhana, 2008 p: 2).

Sereh merupakan tanaman herba menahun yang membentuk rumpun tebal dengan tinggi sampai 1 meter. Minyak sereh yang diperoleh dengan cara menyuling daunnya, digunakan untuk obat gosok, pewangi pada sabun mandi (Sastrapradja, S, dkk, 1980 p: 105). Secara tradisional, tanaman ini dapat digunakan sebagai tanaman obat dan rempah (Taufiq, Tuhana, 2008 p: 6).

Minyak atsiri dikenal juga dengan nama minyak terbang, minyak eteris, essential oil atau volatile oil, yang dihasilkan oleh tanaman. Minyak atsiri mudah menguap pada suhu kamar, mempunyai rasa getir, berbau wangi sesuai dengan bau tanaman penghasilnya (Ketaren, S, 1985: 21).

Minyak sereh yang dihasilkan dengan cara penyulingan daun sereh mengandung kurang dari 0,5 - 1,2 persen minyak. Bahan kimia yang terpenting dalam minyak sereh adalah persenyawaan aldehid dengan nama sitronellal dan persenyawaan alkohol disebut geraniol (Ketaren, S, 1985 p: 204). Randemen minyak yang dihasilkan dari rumput sereh tergantung bermacam-macam faktor antara lain : iklim, kesuburan tanah, umur tanaman, dan cara penyulingan (Ketaren, S, 1985 p: 210).

Tanaman sereh wangi mulai dipanen pada umur 6 bulan setelah tanam dengan cara memangkas atau memotong daun dari rumpun tanaman. Pemangkasan berikutnya setiap 3 bulan sekali tergantung dari kondisi tanamannya (Kardinan, Agus, 2005 p: 51).

Prinsip penyulingan minyak atsiri yang terdapat di dalam suatu bahan dapat dilakukan dengan tiga macam cara, yaitu penyulingan dengan air (direbus), penyulingan dengan air dan uap (dikukus), penyulingan dengan uap (diuapkan) (Taufiq, Tuhana, 2008 p: 27). 


\section{METODOLOGI PENELITIAN}

\section{Variabel Penelitian}

Menurut Dr.Soekidjo Notoatmojo dalam buku Metodologi Penelitian Kesehatan halaman 70, variabel penelitian terdiri dari variabel dependent atau variabel tergantung dan variabel independent atau variabel bebas. Dalam penelitian ini variabel dependentnya adalah hasil rendemen minyak atsiri sereh dengan destilasi air. Sedangkan variabel independentnya adalah tanaman sereh yang umur panennya 6 bulan dan 9 bulan.

\section{Prosedur Pemilihan Sampel dan Sampel Penelitian}

Prosedur pemilihan sampel dan sampel penelitian, langsung dengan objek penelitian yaitu tanaman sereh umur panennya 6 bulan diambil dari 1 rumpun dan 9 bulan diambil dari 1 rumpun.

\section{Cara Kerja dalam penelitian adalah} sebagai berikut :

Ke dalam labu bervolume 2 liter (dengan dasar bulat) ditambahkan bahan mengandung minyak yang telah dirajang. Tambahkan air dalam labu sebanyak 3 - 6 kali berat bahannya, atau rata-rata sekitar 4 kali berat bahan.
Hubungkan pipa dengan kondensor dan tambahkan air sampai memenuhi pipa. Labu ditempatkan dalam bantalan labu dan dipanaskan dengan pemanas listrik atau dengan nyala Bunsen sampai mencapai suhu $130^{\circ}$ C. Pemanasan perlu diatur sehingga kecepatan penyulingan sebanyak 1 tetes per detik. Lanjutkan penyulingan sampai tidak terdapat tetes minyak, yang biasanya membutuhkan waktu $5-6$ jam. Setelah penyulingan selesai, minyak dibiarkan beberapa saat, agar air dan minyak terpisah secara sempurna, dan minyak menjadi dingin pada suhu kamar. Jumlah ml minyak atsiri yang diperoleh dapat dihitung (biasanya dinyatakan dengan persentase volume minyak/berat bahan) (Ketaren, S, 1985 p: 139).

\section{Teknik Pengolahan dan Analisis Data:}

Analisa hasil penelitian menggunakan analisa kuantitatif untuk menghitung rendemen minyak atsiri sereh dengan statistik uji rata-rata, dan perhitungan uji-t dengan taraf kepercayaan $95 \%$.

1. Evaluasi organoleptis dengan mengamati bentuk, warna, rasa dan bau minyak atsiri sereh. 
2. Analisa kuantitatif untuk menghitung rendemen minyak atsiri sereh.

$$
\text { Rendemen }(\%)=\frac{\text { Volume miny ak atsiri }(\mathrm{ml})}{\text { Berat Simplisia }(\text { gram })} \times 100 \%
$$

3. Teknik pengolahan data dalam penelitian ini menggunakan analisis statistik uji-t dengan pengujian nilai rata-rata dua kelompok sampel yang saling bebas dan membandingkan data tersebut. Jika thitung < t-tabel, maka berarti kedua ratarata tidak berbeda signifikan, sehingga $\mathrm{H}_{0}$ diterima dan $\mathrm{H}_{\mathrm{a}}$ ditolak.

Rumus :

$$
\begin{aligned}
t-\text { hitung } & =\frac{\left(\overline{\mathrm{X}}_{1}-\overline{\mathrm{X}}_{2}\right)}{\sqrt{\frac{\left(n_{1}-1\right) S_{1}^{2}+\left(n_{2}-1\right) S_{2}^{2}}{n_{1}+n_{2}-2} \cdot \sqrt{\frac{1}{n_{1}}}}+\frac{1}{n_{2}}} \\
\mathrm{dk}= & \left(\mathrm{n}_{1}-1\right)+\left(\mathrm{n}_{2}-1\right)
\end{aligned}
$$

Keterangan :

$n_{1}$ : Jumlah Sampel ke-1

$n_{2}$ : Jumlah sampel ke-2

$S_{1}^{2}$ : Varian Sampel ke-1

$S_{2}^{2}$ : Varian Sampel ke-2

$\overline{\mathrm{X}}_{1}$ : Rata-rata Randemen Sampel ke-1

$\mathrm{X}_{2}$ : Rata-rata Randemen Sampel ke-2

dk : Derajat kebebasan.

\section{HASIL DAN PEMBAHASAN}

1. Uji determinasi

Hasil uji determinasi sampel tanaman sereh yang digunakan untuk penelitian adalah spesies tumbuhan Cymbopogon citratus yang termasuk dalam familia Poaceae.

2. Evaluasi Organoleptis

Sereh yang umur panennya 6 bulan :

Bentuk : Cairan kental (minyak)

Warna : jernih kekuningan

Bau : Khas aromatik

Rasa : Tajam dan pedas

3. Hasil Randemen Minyak Atsiri

Dari hasil percobaan penetapan kadar minyak atsiri pada sereh (Cymbopogon citratus) yang umur panennya 6 bulan dan yang umur panennya 9 bulan setelah dilakukan sebanyak tiga kali replikasi pada tanaman sereh, didapat hasil randemen sebagai berikut : 
Tabel 4.2. Hasil randemen minyak atsiri sereh (Cymbopogon citratus)

\begin{tabular}{|c|c|c|c|}
\hline $\begin{array}{l}\text { Umur } \\
\text { Panen }\end{array}$ & $\begin{array}{l}\text { Replikasi } \\
\text { Percobaan }\end{array}$ & $\begin{array}{r}\text { Bobot } \\
\text { simplisia } \\
(\text { gram })\end{array}$ & $\begin{array}{c}\text { Hasil } \\
\text { randemen } \\
\% \mathrm{v} / \mathrm{b} \\
(\mathrm{ml} / \mathrm{gram})\end{array}$ \\
\hline \multirow{4}{*}{6 bulan } & I & 100 & 0,41 \\
\hline & II & 100 & 0,49 \\
\hline & III & 100 & 0,47 \\
\hline & \multicolumn{2}{|c|}{ Rata - rata } & 0,46 \\
\hline \multirow{4}{*}{9 bulan } & I & 100 & 0,30 \\
\hline & II & 100 & 0,36 \\
\hline & III & 100 & 0,39 \\
\hline & \multicolumn{2}{|c|}{ Rata - rata } & 0,35 \\
\hline
\end{tabular}

Dapat dilihat hasil randemen rata-rata minyak atsiri sereh yang umur tumbuhnya 6 bulan sebesar $0,46 \%$ v/b dan randemen rata-rata minyak atsiri sereh yang umur panennya 9 bulan sebesar 0,35\% v/b.

Hasil penelitian dilakukan analisis ujit dengan taraf kepercayaan 95\% karena sampel yang digunakan sedikit serta replikasinya hanya 3 kali. Hasil perhitungan uji-t terdapat pada lampiran 3. Penggunaan uji-t adalah untuk mengetahui perbedaan nilai rata-rata antara dua kelompok, sedangkan penggunaan t-test independent adalah untuk mengetahui perbedaan nilai rata-rata antara satu kelompok dengan kelompok yang lain, dimana satu kelompok dengan kelompok yang lain tidak saling berhubungan.

Hasil perhitungan uji-t yang terdapat pada lampiran 3 menunjukan adanya perbedaan bermakna antara sereh yang umur panennya 6 bulan dan umur panennya 9 bulan dengan t-hitung $(2,984)$ $>$ t-tabel $(2,776)$ dan daerah penolakan hipotesis nol terdapat pada lampiran 5. Berdasarkan harga t-hitung lebih besar daripada harga tabel dari distribusi-t dengan taraf kepercayaan $95 \%$ maka $\mathrm{H}_{0}$ ditolak, Ha diterima artinya ada perbedaan yang signifikan antara randemen minyak atsiri sereh yang umur panennya 6 bulan dan 9 bulan.

Hasil penelitian ini menunjukkan bahwa tanaman sereh yang umur panennya 6 bulan lebih banyak menghasilkan minyak atsiri dibandingkan dengan tanaman sereh yang umur panennya 9 bulan. Hal ini dipengaruhi oleh beberapa faktor, diantaranya iklim, umur panen. Tanaman sereh umur 6 bulan merupakan umur optimal untuk dipanen, sehingga mendapatkan rendemen minyak atsiri yang lebih besar, disamping itu faktor kesuburan tanah serta intensitas cahaya matahari juga berpengaruh terhadap 
kandungan minyak atsiri sereh.

\section{KESIMPULAN}

Dari hasil penelitian yang telah dilakukan pada sampel uji, dapat disimpulkan bahwa hasil randemen minyak atsiri pada tanaman sereh (Cymbopogon citratus) yang umur panenya 6 bulan diperoleh hasil randemen rata-rata $0,46 \% \mathrm{v} / \mathrm{b}$ dan 9 bulan diperoleh randemen rata-rata $0,35 \% \mathrm{v} / \mathrm{b}$ dengan hasil uji-t didapatkan harga t-hitung $(2,984)>$ t-tabel $(2,776)$. Sehingga $\mathrm{H}_{0}$ ditolak dan $\mathrm{H}_{\mathrm{a}}$ diterima dan dapat disimpulkan bahwa terdapat perbedaan yang signifikan antara sereh yang umur panennya 6 bulan dan 9 bulan.

\section{SARAN}

Dari hasil penelitian yang dilakukan, peneliti menyarankan perlu dilakukan penelitian lebih lanjut mengenai minyak atsiri dengan objek dan metode yang berbeda.

\section{DAFTAR PUSTAKA}

Anonim. 1985. Tanaman Obat Indonesia jilid II. Departemen Kesehatan Republik Indonesia. Jakarta. hal: 42.

Departemen Kesehatan RI. 1979. Farmakope Indonesia, Edisi III. Jakarta : UIPress. hal: 813.

Harborne, J, B. 1987. Metode Fitokimia.

Bandung : ITB. hal: 37.
Kardinan, Agus. 2005. Tanaman Penghasil Minyak Atsiri. Jakarta: Agro Media Pustaka. hal: 1, 5, 6, 7, 8, 51, 52, 67, 68, 69.

Ketaren, S. 1985. Pengantar Teknologi Minyak Atsiri. Jakarta: Balai Pustaka. hal: 21, 27, 28, 47, 67, 68, 139, 204, 206, 208, 210, 212.

Notoatmodjo, Soekidjo. 2002. Metodologi Penelitian Kesehatan. Yogyakarta : PT Rineka Cipta. hal: 70.

Riwidikdo. 2009. Statistik untuk Penelitian Kesehatan. Yogyakarta: Pustaka Rihama. hal 80.

Sastrapradja, S., dkk. 1980. Tanaman Industri. Lembaga Biologi Nasional. LIPI. Jakarta: PN Balai Pustaka hal: 105.

Sudjadi. 2007. Kimia Farmasi Analisis. Yogyakarta : Pustaka Pelajar. hal 19.

Sugiyono. 2006. Statistik untuk Penelitian. Bandung:Alfabeta. hal: 134-138.

Taufiq, Tuhana. 2008. Menyuling Minyak Atsiri. Yogyakarta: Citra Aji Parama. hal: 2, 6, 27, 29, 40. 